\title{
İran ve Türkiye'nin Dünya Bilgibilim Literatürüne Katkıları: Karşılaştırmalı Bir Çalışma
}

\author{
Contributions of Iran and Turkey to the World Information \\ Science Literature: A Comparative Study
}

Umut AL* ve Mehdi AFZALi**

\begin{abstract}
Öz
Bu makalede Iran ve Türkiye'nin dünya bilgibilim literatürüne katkıları araştırılmaktadır. Bu amaçla, çalışmamızda Social Sciences Citation Index (SSCl) kapsamında yer alan dergilerde yayımlanmış Iran ve Türkiye adresli yayınlar incelenmektedir. İki ülkenin bilgibilim dergilerinde toplam 140 yayını bulunmaktadır. Söz konusu yayınların 85'i Türkiye'ye, 55'i ise Iran'a aittir. Periyodik olarak bakıldığında, İan adresli yayınların zaman içinde artış ve azalışlar gösterdiği, buna karşııı Türkiye adresli yayınların sayısının her geçen yıl artıığ görülmektedir. Iranlı araştırmacıların en çok yayın yaptığı bilgibilim dergisi International Information \& Library Review iken, Türkiye adresli yayınlar en sık Scientometrics adlı dergide yer almıştır. Türkiye adresli yayınların Iran adresli yayınlara oranla daha sık bir şekilde birden çok yazarın katkısı ile oluştuğu görülmektedir. Iran adresli yayınların yazarlarının çoğunlukla kütüphanecilik kökenli olduğu gözlenirken, Türkiye adresli yayınların yazarları arasında istatistik, endüstri mühendisliği ve fizik gibi farkı alanlardaki araștırmacıların bulunduğu görülmektedir. Üretilen yayın sayısının ülkelerin potansiyelini tam olarak yansıtmadığı düşünülmektedir. Bu bağlamda, Iran ve Türkiye'nin gelecekte yapacakları araştırmalar ile bilgibilim dünyasında daha etkin bir konumda olması gerekmektedir.
\end{abstract}

Anahtar sözcükler: Bibliyometri, Bilgibilim dergileri, Ulusal üretkenlik-Iran, Ulusal üretkenlik-Türkiye.

\footnotetext{
* Arş. Gör.; Hacettepe Üniversitesi Bilgi ve Belge Yönetimi Bölümü Beytepe 06532-Ankara (umutal@hacettepe.edu.tr).

${ }^{* *}$ Dr. Adayı; Hacettepe Üniversitesi Bilgi ve Belge Yönetimi Bölümü Beytepe 06532-Ankara (afzali@hacettepe.edu.tr).
} 


\begin{abstract}
This article investigates the contributions of Iran and Turkey to the world information science literature. In this context, the study examines Iran and Turkey addressed publications in the Social Sciences Citation Index (SSCI). Total number of publications of two countries in the information science journals was 140; 85 from Turkey and the remaining 55 from Iran. When analyzed in tenyear time periods, the number of Iran addressed publications shows a kind of instability with certain rise and decline whereas the number of Turkey addressed publications appears to rise steadily. The most preferred information science journal for Iran is International Information \& Library Review while for Turkey it is Scientometrics. More collaborative work is preferred by Turkish scholars than their colleagues in Iran. The majority of Iranian publications come from authors with a librarianship background whereas Turkish publications include authors with different backgrounds such as statistics, industrial engineering and physics. It is pointed out in this article that the number of publications from both countries does not match their potentials. In this respect, both countries need to increase their contributions and thus have a better position in the world of information science.
\end{abstract}

Keywords: Bibliometrics, Information science journals, National productivityIran, National productivity-Turkey.

\title{
Giriş
}

Atıf dizinleri (citation indexes) kapsamında yapılan yayınlara verilen önem günden güne artmaktadır. Araştırmacılar atıf dizinlerinde bulunan dergilerde yayın yaparak yayınlarının daha geniş kitlelerce okunmasını istemektedirler. Aynı zamanda, atıf dizinlerinde yayın yapmanın saygınlık göstergesi olarak algılandığı da bilinmektedir. Her ne sebeple olursa olsun gerçek olan şudur ki; zaman içinde hem atıf dizinleri kapsamında yer alan yayın sayısında, hem de bu dizinlerde yer alan kaynaklarda yayın yapmak isteyen araştırmacı sayısında ciddi bir artış gözlenmektedir. Bu artıştan bilgibilim (information science) literatürü de kendine düşen payı almaktadır. Çalışmamız birçok açıdan benzer özellikler gösteren iki ülke olan İran ve Türkiye'nin dünya bilgibilim literatürüne yapmış oldukları katkının boyutlarını göstermeyi amaçlamaktadır.

Dünya genelinde araştırmacılar tarafından belirli alanlarda literatüre yapılan katkıların araştırılmasında atıf dizinlerinin temel alındığı görülmektedir. Atıf dizinlerinin yaygın olarak kullanılması ve göreceli olarak önemli kabul edilmesinin yanı sıra, verilerin çevrimiçi (online) erişilebilirliği bibliyometrik araştırmalarda atıf dizinlerinden yararlanılmasının en önde gelen sebepleri 
arasında yer almaktadır. Bu bağlamda araştırmamız da Social Sciences Citation Index (SSCl) veri tabanında yer alan verilere dayanılarak gerçekleştirilmektedir.

İran ve Türkiye sınır komşusu olmalarının yanı sıra tarihsel olarak ortak bir geçmişe sahiptir. Tarihte iki ülkenin zaman zaman birlikte hareket ettikleri ve ortak çıkarları doğrultusunda işbirliği yaptıkları bilinmektedir. Bilgibilim alanında da her iki ülkedeki gelişim sürecinin benzerlik taşıyan noktaları bulunmaktadır. Bununla birlikte, alanla ilgili önemli sayılabilecek olayların iki ülkede de 10-15 yıllık arayla, aynı dönemler içinde gerçekleştiği unutulmamalıdır. Örneğin Türkiye'de kütüphanecilik eğitimine 1954-1955 öğretim yılı itibariyle Ankara Üniversitesinde başlanırken; İran'da ilk kütüphanecilik bölümü 1966 yılında Tahran Üniversitesinde kurulmuştur. Her iki bölümde uzun bir süre yurt dışından destek alınarak yabancı hocaların katkıları ile faaliyetlerini sürdürmüştür. Her iki ülkede de üniversitelerde kütüphanecilik eğitimi başlamadan önce kütüphanecilik kursları düzenlenmiştir. Bazı kütüphanecilik bölümlerinin (Tahran ve Hacettepe Üniversitelerindekiler gibi) ilk açıldıklarında sadece lisansüstü düzeyde öğrenci kabul etmiş olmaları da benzerlik taşıyan bir başka önemli noktadır (Ebrami, 1975, ss. 40-41; Ensarı, 1975, s. 532; Ersoy, 1969, s. 228; Harvey, 1989, s. 180; Ötüken, 1979, ss. 71-72).

Mesleki dernekler açısından bakıldığında; Türk Kütüphaneciler Derneği 1949 yılında kurulurken İran'daki ilk kütüphanecilik derneğinin 1965 yılında açıldığı görülmektedir. Günümüzde bilgibilim alanındaki dernek sayısı İran'da yediye ulaşırken, Türkiye'de bu sayı üçtür. Her iki ülke için büyük önem arz eden millî kütüphanelerin kuruluş yılları İran ve Türkiye için sırasıyla 1937 ve 1946 'dır. İki ülkenin kütüphanecilik tarihinde ulusal dokümantasyon merkezlerinin de ayrı bir rolü bulunmaktadır. Türkiye Bilimsel ve Teknik Dokümantasyon Merkezi (TÜRDOK) 1966 yılında; İran Dokümantasyon Merkezi (IRANDOC) ise 1968 yılında kurulmuştur. (Harvey, 1989, s. 185; Kum ve Erdoğan, 1980, s. 252; Ötüken, 1979, s. 14; Soltani ve Rastin, 2001, s. 381).

Günümüzde Bilgi ve Belge Yönetimi Bölümü adı altında Türkiye'de altı farklı üniversitede eğitim-öğretim verilmektedir. İran için bu sayı çok daha fazla olup, 22 farklı üniversitede bilgibilim bölümleri1 faaliyet göstermektedir. Türkiye'deki bilgi ve belge yönetimi bölümlerinde görev yapmakta olan toplam öğretim elemanı sayısı 72'dir ve bunun yaklaşık yarısı (35 kişi) öğretim üyelerinden oluşmaktadır.2 İran'da ise 22 bölümde, 42'si öğretim üyesi olan toplam 99 öğretim elemanı görev yapmaktadır (LISDIRAN, 2006).

1 Iran'da bilgibilim alanında faaliyet gösteren bölümler iki ad altında toplanmaktadır. Bunlar Tıbbi Bilgi Yönetimi ile Kütüphanecilik ve Bilgibilim Bölümü'dür.

2 Söz konusu rakamlar üniversitelerin Bilgi ve Belge Yönetimi Bölümlerinin web sitelerinden derlenerek elde edilmiştir. 
Bu araştırmada İran ve Türkiye'nin bilgibilim alanındaki dergilere olan katkısı irdelenmekte, bu ülkelerin atıf dizinleri kapsamındaki yapmış oldukları yayınlar bibliyometrik özellikleri açısından incelenmektedir. Çalışmamızda ülkelerin yaptıkları yayınları temel almak suretiyle benzerlik ya da farkıııkların olup olmadığına ve daha önemlisi üretken bilgibilim camialarına sahip olabilmeleri için yapılması gerekenlere dikkat çekilmektedir.

\section{Önceki Çalışmalar}

Literatüre bakıldığında, atıf dizinleri kapsamında gerçekleştirilen ve İran ile Türkiye'nin kimi zaman birlikte, kimi zaman tek başlarına ele alınarak yayın performanslarının değerlendirildiği pek çok çalışma bulunmaktadır. Bu çalışmaların önemli bir kısmı (Al, Şahiner ve Tonta, 2006; Osareh ve Wilson, 2002, 2000; Tonta ve İlhan, 1997; Gülgöz, Yedekçioğlu ve Yurtsever, 2002; Uzun, 1998; Wilson ve Osareh, 2003; Yurtsever, Gülgöz, Yedekçioğlu ve Tonta, 2002, 2001) ülkeleri tek başına değerlendirmekte ve belli bir atıf dizininde o ülkenin yayın üretimine ait ayrıntılar sunmaktadır. Literatürde bibliyometrik olarak iki ülkenin doğrudan karşılaştırıldığı herhangi bir çalışmaya rastlanılmamıştır. Çoğunlukla iki ülkenin isimlerinin birlikte geçtiği araştırmalar, ülkelerin yayınlarına ait verilerin tablolardaki birer satır değeri olarak verildiği çalışmalardır (Côté ve Archambault, 2005; Ensafi ve Gharibi, 2002; Garfield, 1983; Osareh ve Wilson, 1997).

Farklı çalışmalarda, ülkeler bazında yapılan sınıflamalarda, İran ve Türkiye'nin aynı grup içinde yer aldığı görülürken, sınıflama başlığı kimi zaman coğrafik (Ortadoğu gibi - Uzun, 1996), kimi zaman politik (üçüncü dünya gibi - Garfield, 1983), kimi zaman ise ekonomik (gelişmekte olan - Côté ve Archambault, 2005) olmaktadır. Coğrafik konuma göre yapılan sınıflamanın sonucu olan çalışmalardan birinde, İran ve Türkiye ile birlikte Mısır, Irak, Ürdün, Suudi Arabistan ve Suriye ele alınmakta ve bu inceleme söz konusu ülkelerin fizik yayınlarını kapsamaktadır. Bu çalışmada Ortadoğu ülkelerinin 1990-1994 yılları arasında yapmış olduğu fizik yayınları incelenirken, Science Citation Index (SCI) kapsamında söz konusu ülkelerin 2368 yayının yaratılmasına katkıda bulundukları saptanmıştır. Çalışmada Ortadoğu ülkelerinin dünyadaki fizik yayınları literatürünün sadece \% 1'ini oluşturduğuna dikkat çekilmektedir (Uzun, 1996, s. 268). Üçüncü dünya ülkelerinde yayımlanan makalelerin ve bu makalelere yapılan atıfların incelendiği başka bir çalışmada, en üretken 25 ülke içinde üçüncü dünya ülkesi olarak sınıflanan ülkelerden sadece Hindistan ve Arjantin'in yer aldığını görülmektedir. Bu çalışmada en üretken üçüncü dünya ülkeleri arasında, 196 makale ile İran dokuzuncu, 184 makale ile Türkiye onuncu sırada yer almaktadır (Garfield, 1983, ss. 257-258). 
İran ve Türkiye'nin atıf dizinleri kapsamında yer alan yayınlarının sayısında son yıllarda ciddi bir artış gözlenmektedir. Söz konusu artışın boyutları farklı çalışmalarda (Ensafi ve Gharibi, 2002; Gülgöz, Yedekçioğlu ve Yurtsever, 2002; Mehrdad, Heydari, Sarbolouki ve Etemad, 2004; Moin, Mahmoudi ve Rezaei, 2005; Osareh ve Wilson, 2002; Tonta ve İlhan, 1997; Wilson ve Osareh, 2003) gözler önüne serilmektedir. SSCl veri tabanında 31 Mart 2006 tarihi itibariyle yaptığımız taramada, İran'a ait 1336, Türkiye'ye ait 4871 yayının olduğu saptanmıştır. Daha önce yapılan bir araştırmada (Tonta ve İlhan, 1997, s. 40) ise 1972-1996 yılları arasında SSC/de Türkiye'ye ait 1360 yayının dizinlendiği bilgisi verilmektedir. Bu rakam, günümüzde ulaşılan sayı ile karşılaştııılığında üç katın üzerinde bir artışın olduğu görülmektedir. İran için de, bu denli olmasa bile bir artış söz konusudur. İran adresli olarak SSC/de yaptığımız tarama sonucunda, 1972-1996 yılları arasında 599 yayının, 1997 yılı ve sonrasında 703 yayının yapıldığı görülmektedir (ISI, 2006).

Literatürde, çalışmamızın yöntemiyle paralellik gösteren ve bu bağlamda Journal Citation Reports'daki (JCR) bilgibilim alanındaki dergilerin temel alınarak bu dergilerdeki yayınların incelendiği bazı çalışmalar (HerreroSolana ve Ríos-Gómez, 2006; Schloegl ve Stock, 2004) da bulunmaktadır. Bunlardan bir tanesi (Herrero-Solana ve Ríos-Gómez, 2006) 1992-2002 yılları arasında yayımlanmış $J C R^{\prime}$ lerde bulunan bilgibilim dergilerinden yararlanarak 1966-2003 yılları arasındaki Latin Amerika'nın bilgibilim literatürüne olan katkısını incelemektedir. Makalede en verimli ülkenin Brezilya olduğu ve yayınların yarısının bu ülke tarafından üretildiği ifade edilmektedir. JCR'de yer alan dergilerin temel alındığı bir başka çalışmada (Schloegl ve Stock, 2004) ise, 50 dergideki yaklaşık 90.000 atıf incelenmektedir. Söz konusu çalışma atıf analizi ve okuyucu araştırması olmak üzere iki aşamadan oluşmakta ve atıf analizi verileri ile anket yoluyla okuyuculardan elde edilen veriler karşılaştırılmaktadır. Araştırmada farklı değişkenler (okuma sıklığı ile etki faktörü3; okuma sıklığı ile yarı yaşam4; okuma sıkığı ile makale başına düşen referans sayısı gibi) arasında ilişki bulunup bulunmadığı sınanmaktadır. Örneğin, dergilerin okunma sıklığı ile dergilerin etki faktörü arasındaki ilişkiye bakılmış, etki faktörünün okuma davranışını etkilemediği görülmüştür (Schloegl ve Stock, 2004, s. 1166).

Bilgibilim dergileri üzerine yapılan bibliyometik bir başka çalışmada (Uzun, 2002) JCR'ye dayanan bir sınıflama yapılmaksızın, yazar tarafından

3 Bir derginin geçmiş iki yılda yayımladığı makalelerin toplamına o yıl içerisinde alınan atıfların, geçmiş iki yıl içinde yayımlanan makale sayısına oranı derginin etki faktörünü vermektedir (Garfield 1994).

4 Yarı yaşam, atıf ya da istek yapılan kaynakların ortanca yaşı olarak tanımlanmaktadır (Line 1970, s. 46). 
çekirdek bilgibilim dergileri olarak kabul edilen ve SSCI kapsamında bulunan 21 dergide yayımlanan makalelerin incelendiği görülmektedir. Araştırmada Doğu Avrupa ülkeleri ile gelişmekte olan ülkelerin bilgibilim alanındaki yayınları bibliyometrik bir bakış açısıyla ele alınmaktadır. Çalışma 1980-1999 yılları arasında söz konusu ülkelerin bilgibilim alanındaki makale üretiminin oldukça sınırlı olduğunu göstermekte, tüm makalelerin \% 8'inin bu ülkelerin yazarları tarafından yayımlandığı ifade edilmektedir (Uzun, 2002, s. 21).

\section{Yöntem}

Çalışmanın amacı, İran ve Türkiye'nin dünya bilgibilim literatürüne yapmış oldukları katkının boyutlarını göstermek, söz konusu yayınları inceleyerek iki ülkenin atıf dizinleri kapsamında yer alan yayınlarını bibliyometrik özellikleri açısından karşılaştırmaktır. Araştırmamızda aşağıdaki sorulara yanıt aranmaktadır:

- Bilgibilim alanında atıf dizinleri kapsamında yer alan yayınların ne kadarı İran ve Türkiye adreslidir?

> İran ve Türkiye'ye ait yayınlar en sık hangi bilgibilim dergilerinde yayımlanmıştır?

> Her iki ülkenin yayınlarını yayımladıkları dergiler ile bu dergilerin etki faktörleri arasında istatistiksel açıdan anlamlı bir korelasyon bulunmakta mıdır?

- Atıf dizinleri kapsamındaki bilgibilim dergilerinde yapılan yayınların ne kadarı bilgibilim kökenli araştırmacılar tarafından gerçekleştirilmiştir?

> Her iki ülkenin bilgibilim alanındaki yayınları literatürde ne kadar atıf almıştır?

> Ülkelerin bilgibilim camialarının ortaklaşa yayın üretmekteki konumları nedir?

Atıf dizinlerinde yer alan, İran ve Türkiye'ye ait bilgibilim alanındaki yayınları saptayabilmek amacıyla SSCI veri tabanında 31 Mart 2006 tarihinde çevrimiçi bir tarama gerçekleştirilmiştir. Veri tabanında yapılan taramada "kaynak başlığı" (source title) bölümüne dergi adları, adres bölümüne ise ülke adları yazılmıştır. Dergilerin adları Journal Citation Reports (JCR) 2004'te "Bilgibilim ve Kütüphane Bilimi" (Information Science \& Library Science) alanı altında bulunan bilgilerden yararlanılarak elde edilmiştir. JCR 2004 'te ilgili alanda 54 dergi yer almaktadır (ISI, 2004). Daha önceki yıllarda da bu alanda dergiler olabileceği düşünülerek eski yıllara ait $J C R^{\prime}$ lere de bakılmıştır. Tüm bu tarama sürecinden sonra söz konusu alana ilişkin atıf dizinlerine girmiş 66 derginin bulunduğu saptanmıştır. 
Yapılan tarama sonucunda İran ve Türkiye adresli bilgibilim dergilerinde yayımlanmış tüm yayınlar saptanmıştır. Bu çalışmada "yayın" terimi makale, kitap tanıtımı, editoryal, kısa not, mektup ve yazılım inceleme türündeki yazıları kapsamaktadır.

Yayınların niteliğine ilişkin kestirimlerde bulunabilmek amacıyla, ISI tarafından yayımlanan JCR'de dergilere yönelik olarak hazırlanan etki faktörü verilerinden yararlanılmıştır. Her bir derginin etki faktörü saptanmış, elde edilen veriler dergilerde yayın yapılma sıklıkları ile karşılaştıılarak dergilerin etki faktörleri ile söz konusu dergilerde yayın yapılması arasında bir korelasyon olup olmadığı test edilmiştir. Dergilerin etki faktörlerini belirlerken $J C R$ 'de yer aldıkları en son yıla ait değer temel alınmıştır.

Sayıları az olmakla birlikte bazı dergilerin zaman içinde ad değiştirdiği görülmüştür. Değerlendirmenin sağlıklı yapılabilmesi için öncelikle dergilerin ad değiştirip değiştirmediği saptanmış, ad değişikliği olanların eski ve yeni adlarının birlikte ele alınabilmesi amacıyla veriler dergilerin en yeni adları altında toplanmıştır.

Çalışmamızın iyi değerlendirilebilmesi için gözden kaçırılmaması gereken üç nokta bulunmaktadır. Bunlardan ilki, araştırmamızda iki ülkeden herhangi birinin vatandaşı olunmasına değil, araştırmacının/araşıırmacıların söz konusu ülke adresli yayın yapıp yapmadığına bakılmaktadır. İkinci önemli nokta, araştırmamız ISl'nin yapmış olduğu sınıflandırmaya dayalı olarak yapılandırımıştır. Bu sınıflandırmada bazı dergilerin doğrudan bilgibilime yönelik olduğu, bazılarının ise dolaylı yoldan bir ilişki kurularak bu alan altında yer aldığı bilinmektedir. Üçüncü olarak ise, İran ve Türkiye'deki bilgibilim alanındaki kişilerin bilgibilim dergileri dışında kalan farklı dergilerde de yayın yaptıklarının unutulmaması gerektiğidir. Doğal olarak bu tür yayınlar araştırma kapsamında ele alınmamıştır.

Çalışmamız iki ülkeden birisinin (İran'ın) SSClde ilk kez yayınının yer aldığı yı (1967) ile 2006 yılı arasını kapsamaktadır. Yayın yılı 2006 olan ve bilgibilim dergilerinde yer alan yayınların önemli bir kısmının taramayı yaptığımız tarihte $S S C l$ tarafından dizinlenmediği dikkate alınmalıdır. Taramalar sonucunda elde edilen veriler, SPSS ve Excel yazılımlarından yararlanılarak değerlendirilmiştir.

\section{Bulgular ve Yorum}

Araştırmamız kapsamında incelenen toplam yayın sayısı 140'dır. Bu yayınların 85 'i Türkiye, 55'i ise İran adreslidir. Atıf dizinleri kapsamındaki bilgibilim dergilerinde, İran adresli yayınların Türkiye adresli yayınlardan daha önce yer aldığı görülmektedir. Bilgibilim dergilerinde İran'a ait ilk yayının yılı 1967, Türkiye'ye ait ilk yayının yılı ise 1974'tür. Şekil 1'de onar yıllık dönemler halinde iki ülkenin yayın sayıları verilmektedir. 
Şekil 1: İran ve Türkiye'nin Bilgibilim Dergilerindeki Yayınları

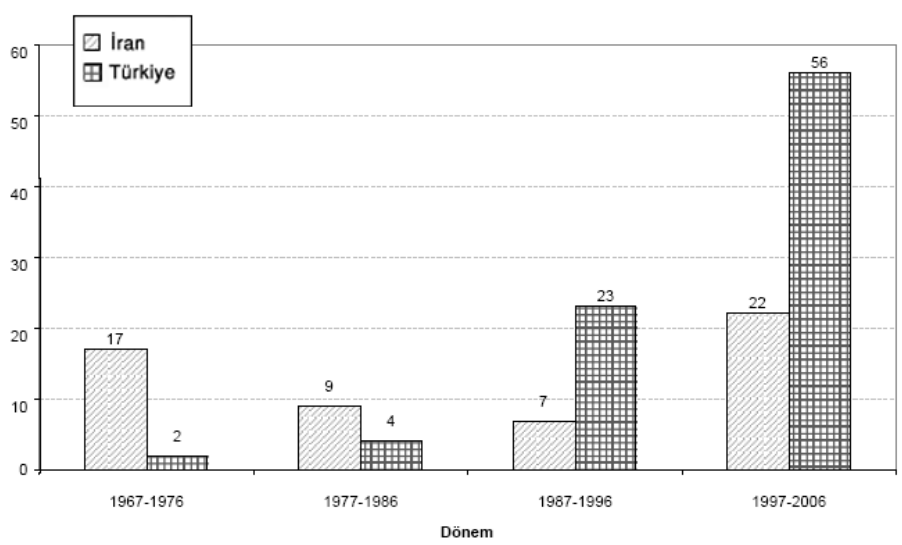

Şekil 1 son zamanlarda bilgibilim dergilerindeki Türkiye adresli yayın sayısının artışını göstermekle birlikte; İran'ın dört dönemlik performansında ilk döneme (1967-1976) ait yayınların ikinci (1977-1986) ve üçüncü dönem (1987-1996) yapılan yayınlardan daha fazla olduğunu da ortaya koymaktadır. Hiç şüphesiz İran'ın yayın sayısında, söz konusu dönemlerdeki azalışta iki olayın çok önemli etkisi bulunmaktadır. Bunlardan ilki İran İslam Devrimi, ikincisi ise İran-Irak Savaşı'dır. İslam Devrimi yabancı hocaların kendi ülkelerine dönmelerine neden olmuş, İran'da yaşanan siyasi çatışmalar ve ülkedeki iç savaş nedeniyle de Haziran 1980'den itibaren ülkedeki tüm üniversiteler kapatılmıştır. Özellikle iç savaş ve öğrenci olaylarının etkisinin devam etmesi sonucu üniversitelerin tekrar açılması 1983 yılını bulmuştur. Öte yandan, yine aynı yıllarda (Eylül 1980) İran-Irak Savaşı'nın başlaması ülkede önemli yaralar açmıştır. Tüm bu olaylar yaklaşık üç milyon insanın göç etmesine ya da sürgüne yollanmasına neden olmuştur. Doğal olarak bu kişiler arasında çok sayıda öğretim üyesi ve bilim adamı bulunması, ülkedeki bilimsel yayın faaliyetlerini de olumsuz yönde etkilemiştir. Üniversitelerin kapanmasının dışında, akademisyenlerin ülkeden ayrılması ile de bazı kütüphanecilik okulları (Al-Zahra, Dr. Çemran ve Şiraz Üniversitelerindekiler gibi) kapatılmak zorunda kalmıştır (Mezinani, 2000, ss. 269-270; Mortezayi, 2000).

Tablo 1, 1967 yılından 2006 yılına kadar geçen sürede $S S C l$ kapsamındaki tüm bilgibilim dergilerinde yayımlanan toplam yayın ve makale sayılarını vermektedir. Görüldüğü üzere çalışmamız kapsamındaki ilk dönem olan 1967-1976 yılları arasını kapsayan dönem ile 1977-1986 yılları arasını içeren dönem arasında yayın sayısı neredeyse ikiye katlanmış, yayımlanan makale sayısında ise \% 70 oranında artış görülmüştür. Takip eden dönemlerde oransal olarak bu denli artış görülmemekle birlikte, 1997-2006 döne- 
minde bilgibilim dergilerindeki yayın sayısının neredeyse 100.000 rakamına ulaştığı ortaya çıkmıştır. Bu dönemde söz konusu yayınların yaklaşık olarak beşte biri makalelerden oluşmaktadır.

Tablo 1: Bilgibilim Dergilerindeki Yayın ve Makale Sayıları

\begin{tabular}{|l|c|c|}
\hline Dönem & Yayın sayısı & Makale sayısı \\
\hline $1967-1976$ & 13540 & 6061 \\
\hline $1977-1986$ & 26654 & 10360 \\
\hline $1987-1996$ & 59239 & 15747 \\
\hline $1997-2006$ & 96212 & 19348 \\
\hline
\end{tabular}

Tablo 1 dönemler itibariyle bilgibilim dergilerindeki tüm yayın ve makale sayılarını verirken; Tablo 2, söz konusu dönemlerde bilgibilim dergilerindeki İran ve Türkiye'ye ait yayın ve makale sayılarını içermektedir. Her iki tablodaki ülkelere ait makale sayıları ile dönemler itibariyle SSC/deki bilgibilim dergilerinde yayımlanan makale sayılarına baktığımızda İran ve Türkiye'nin alana yapmış olduğu katkı oransal olarak görülmektedir. İki tablodaki verilerin kullanımıyla İran ve Türkiye'nin makale bazında dünya bilgibilim literatürüne nicel olarak yaptıkları katkı Şekil 2'de sunulmaktadır. Buna göre makale bazında İran'ın bilgibilim dergilerine yapmış olduğu katkı 1967-1976 yıllarını kapsayan dönemde \% 0,25; 1977-1986 arasındaki dönemde \% 0,08; 1987-1996 arasında \% 0,04 iken, 1997-2006 arası \% 0,11'dir. Türkiye'nin katkısına ilişkin oranlar ise 1967-1976 ve 1977-1986 için \% 0,03; 1987-1996 için \% 0,12'dir. Son dönem olarak ele aldığımız 1997-2006 arasında Türkiye adresli olarak yayımlanmış 53 makale ile Türkiye'nin katkısının on binde yirmi yedi $(\% 0,27)$ düzeyine geldiği görülmektedir.

Tablo 2: Bilgibilim Dergilerindeki İran ve Türkiye'ye ait Yayın ve Makale Sayıları

\begin{tabular}{|l|c|c|c|c|}
\hline \multirow{2}{*}{ Dönem } & \multicolumn{2}{|c|}{ İran } & \multicolumn{2}{c|}{ Türkiye } \\
\cline { 2 - 5 } & Yayın sayısı & Makale sayısı & Yayın sayısı & Makale sayısı \\
\hline $1967-1976$ & 17 & 15 & 2 & 2 \\
\hline $1977-1986$ & 9 & 8 & 4 & 3 \\
\hline $1987-1996$ & 7 & 6 & 23 & 19 \\
\hline $1997-2006$ & 22 & 21 & 56 & 53 \\
\hline Toplam & 55 & 50 & 85 & 77 \\
\hline
\end{tabular}


Şekil 2. İran ve Türkiye'nin Makale Bazında Dünya Bilgibilim Literatürüne Katkıları

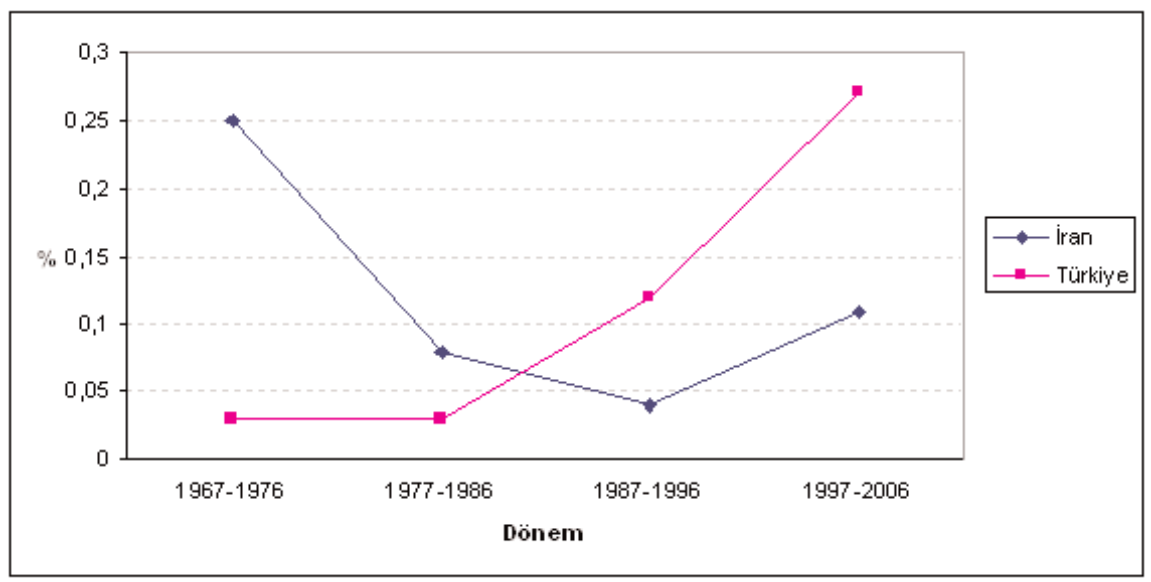

Yayınlar bibliyometrik açıdan incelendiğinde, yayınların dilinin aynı olduğu görülmektedir. Hem Türkiye hem de İran adresli yayınların tamamının dili İngilizcedir. Bu durum bilgibilim alanında atıf dizinlerine giren ve dili İngilizce olmayan çok az sayıda derginin bulunmasından kaynaklanmaktadır. Öte yandan her iki ülkenin de atıf dizinleri kapsamında herhangi bir bilgibilim dergisi bulunmamaktadır. ${ }^{5}$ Bununla birlikte atıf dizinleri kapsamında İran adresli beş, Türkiye adresli yedi adet dergi bulunmaktadır. Atıf dizinlerinde yer alan İran adresli beş dergi; Iranian Journal of Chemistry \& Chemical Engineering, Iranian Journal of Science \& Technology, Iranian Journal of Science \& Technology Transaction A-Science, Iranian Journal of Science \& Technology Transaction B-Engineering ve Iranian Polymer Journal adlı dergilerdir. Journal of Sports Science \& Medicine, Turkish Journal of Chemistry, Turkish Journal of Earth Sciences, Turkish Journal of Pediatrics, Turkish Journal of Veterinary \& Animal Sciences, Türk Psikoloji Dergisi ile Türk Psikiyatri Dergisi Türkiye'de yayımlanan ve atıf dizinlerine giren dergilerdir.

İran ve Türkiye ile karşılaştırıldığında birçok ülkenin yayın ve makale sayılarının oldukça fazla olduğu görülmektedir. Atıf dizinleri kapsamında Amerika Birleşik Devletleri'nin hemen hemen tüm alanlardaki lider konumunu bilgibilim dergilerine yönelik olarak da görmek mümkündür. Bilgibilim alanında önemli düzeyde üretim yapan diğer ülkeler arasında İngiltere,

5 Türkiye'de 50 yılı aşkın bir süredir yayımlanmakta olan Türk Kütüphaneciliği'nin SSCI kapsamına alınması yolunda birtakım girişimlerin başlatıldığı bilinmektedir (Küçük, 2004, s. 362). 
Kanada, Almanya, Avustralya ve Hollanda yer almaktadır. Bu ülkeler arasında 1997-2006 yılları arasında en az makaleye sahip Hollanda bile Türkiye'den yaklaşık beş kat, İran'dan yaklaşık yedi kat daha fazla makale yayımlamıştır. Tablo 3'de yer alan tüm ülkeler İran ve Türkiye'den daha fazla sayıda yayın ve makale üretmişlerdir. Bununla birlikte tabloda yer almayıp İran ve Türkiye'den daha fazla yayın yapmış Avusturya, Macaristan, Yunanistan, Rusya, Slovenya, Nijerya gibi ülkelerin de bulunduğu unutulmamalıdır.

Tablo 3: Bilgibilim Dergilerinde 100 ve 100 'den Daha Fazla Yayına Sahip Ülkeler (1997-2006)

\begin{tabular}{|c|c|c|}
\hline Ülke & Yayın sayısı & Makale sayısı \\
\hline Amerika Birleşik Devletleri & 61853 & 9927 \\
\hline İngiltere & 2710 & 1385 \\
\hline Kanada & 2134 & 725 \\
\hline Almanya & 981 & 651 \\
\hline Avustralya & 524 & 402 \\
\hline Hollanda & 461 & 364 \\
\hline İskoçya & 386 & 225 \\
\hline Fransa & 381 & 308 \\
\hline Yeni Zelanda & 322 & 121 \\
\hline Çin & 311 & 287 \\
\hline İspanya & 266 & 231 \\
\hline Belçika & 250 & 201 \\
\hline Güney Afrika & 248 & 95 \\
\hline Hindistan & 237 & 187 \\
\hline İtalya & 224 & 163 \\
\hline İsrail & 213 & 149 \\
\hline Tayvan & 204 & 196 \\
\hline Danimarka & 198 & 142 \\
\hline Güney Kore & 189 & 175 \\
\hline Singapur & 189 & 158 \\
\hline İsveç & 187 & 103 \\
\hline Japonya & 182 & 149 \\
\hline Finlandiya & 182 & 165 \\
\hline İsviçre & 124 & 94 \\
\hline Brezilya & 120 & 69 \\
\hline Galler & 106 & 59 \\
\hline Norveç & 100 & 85 \\
\hline
\end{tabular}

Kaynak: Social Sciences Citation Index (ISI, 2006). 
Yayınların türlerine göre dağılımına bakıldığında; önemli bir kısmın makale olduğu görülmektedir. Tablo 4'teki diğer olarak sınıflanan yayın türleri editoryal, yazılım inceleme ve değerlendirmedir. Türkiye adresli olarak SSC/de yer alan yayınlar arasında İran'a ait yayınlardan farklı olarak üç adet yayının not adı altında sınıflandırıldığı ve yayımlanan makale oranlarının birbirine oldukça yakın olduğu saptanmıştır. Bilgibilim dergilerindeki ilk İran adresli makalenin SSClde yer aldığı yılın 1967 olduğu düşünüldüğünde, 40 yıllık bir dönemde 50 makalenin son derece az olduğu düşünülmektedir. İran'dan yedi yıl sonra atıf dizini kapsamındaki bilgibilim dergilerinde ilk makalesi çıkan Türkiye ise, 77 makale ile yılda ortalama iki makale yayımlamıştır. İki ülkenin son 10 yıllık performanslarına baktığımızda geçmiş dönemlere oranla daha üretken oldukları anlaşılmaktadır. Bu dönem itibariyle atıf dizini kapsamında yer alan bilgibilim dergilerinde ortalama olarak her yıl Türkiye adresli beş, İran adresli iki makale yayımlanmıştır. Bu sayıların artışındaki önemli nedenler arasında akademik yükselmelerde atıf dizinlerinde makale sahibi olunması gerekliliği ve ülkelerdeki bazı kurumlar tarafından verilen teşviklerdir. İran'da Bilim, Araştırma ve Teknoloji Bakanlığı, Türkiye'de Türkiye Bilimsel ve Teknolojik Araştırma Kurumu ile Türkiye Bilimler Akademisi atıf dizinlerinde yayın yapılmasını teşvik etmektedir (Atamer, Dorsan, Önder ve Torun, 2002, s. 10; Osareh ve Wilson, 2002, s. 88).

Tablo 4: Yayınların Türlerine Göre Dağııımı

\begin{tabular}{|l|r|r|r|r|}
\hline \multirow{2}{*}{ Yayın türü } & \multicolumn{2}{|c|}{ İran } & \multicolumn{2}{c|}{ Türkiye } \\
\cline { 2 - 5 } Makale & $\mathbf{N}$ & $\%$ & $\mathbf{N}$ & $\%$ \\
\hline Not & 50 & 90,9 & 77 & 90,6 \\
\hline Mektup & - & - & 3 & 3,5 \\
\hline Kitap tanıtımı & 1 & 3,6 & 1 & 1,2 \\
\hline Diğer & 2 & 3,8 & 2 & 2,4 \\
\hline Toplam & 55 & 99,9 & 85 & 100,1 \\
\hline
\end{tabular}

Not: Yuvarlama nedeniyle toplam yüzdeleri \% 100'e eşit değildir.

Yayın Yapılan Dergiler

Araştırmamız kapsamında 66 bilgibilim dergisinde İran ve Türkiye'ye ait yayın olup olmadığına bakılmış, İran ve Türkiye adresli yayınların 38 farklı dergide yayımlandığı saptanmıştır. Bu dergilerin 10 tanesinde (Aslib Proceedings, IFLA Journal, Information Processing \& Management, 
Information Research, International Information \& Library Review, Journal of Academic Librarianship, Libri, Online Information Review, Scientometrics ve Unesco Journal of Information Science Librarianship \& Archives Administration) hem İran, hem de Türkiye adresli yayınlar yer almaktadır.

Bilgibilim dergilerinde İran adresli yayınlar 21 farklı dergide yayımlanmıştır. En çok yayının yapıldığı dergi International Information \& Library Review'dir. Bu dergiyi Libri, Scientometrics ve Unesco Journal of Information Science Librarianship \& Archives Administration izlemektedir. Yayınların yaklaşık yarısı (55 yayının 27'si) bu dört dergide çıkmışır. Tablo 5'de diğer başlığı altında verilen ve sadece birer yayın yapılan bilgibilim dergileri Aslib Proceedings, College \& Research Libraries, Information Research, Information Systems Journal, Journal of Academic Librarianship, Journal of the Medical Library Association, Online, Restaurator ve RQ'dur.

Tablo 5: İran Adresli Yayın Yapılan Bilgibilim Dergileri

\begin{tabular}{lrr}
\hline Dergi adı & N & $\%$ \\
\hline International Information \& Library Review & 13 & 23,6 \\
Libri & 6 & 10,9 \\
Scientometrics & 4 & 7,3 \\
Unesco Journal of Information Science Librarianship & & \\
$\quad$ \& Archives Administration & 4 & 7,3 \\
Electronic Library & 3 & 5,5 \\
Library Journal & 3 & 5,5 \\
Online Information Review & 3 & 5,5 \\
IFLA Journal & 2 & 3,6 \\
Information Processing \& Management & 2 & 3,6 \\
Journal of Government Information & 2 & 3,6 \\
Library Quarterly & 2 & 3,6 \\
Special Libraries & 2 & 3,6 \\
Diğer & 9 & 16,4 \\
Toplam & 55 & 100,0 \\
\hline
\end{tabular}

Tablo 6'da Türkiye adresli yayınların hangi bilgibilim dergilerinde yayımlandıkları verilmektedir. Buna göre en fazla yayının Scientometrics adlı dergide yapıldığı, bunu Information Processing \& Management'in izlediği görülmektedir. International Information \& Library Review, Journal of Information Science, Libri ve Journal of the American Society for Information 
Science \& Technology beşten daha fazla yayının yapıldığı dergiler olarak dikkati çekmektedir. Bu dergiler yayın yapılan tüm dergilerin \% 62'sini oluşturmaktadır. Türk araştırmacılar tarafından sadece birer kez yayın yapılan 11 bilgibilim dergisi olduğu saptanmıştır. Söz konusu dergiler Aslib Proceedings, Government Information Quarterly, Information Society, Interlending \& Document Supply, International Forum on Information \& Documentation, International Journal of Information Management, Journal of Information Technology, Journal of the American Medical Informatics Association, Library Collections Acquisitions \& Technical Services, Program-Automated Library \& Information Systems ve Social Science Information'dır.

Tablo 6: Türkiye Adresli Yayın Yapılan Bilgibilim Dergileri

\begin{tabular}{lrr}
\hline Dergi adı & N & $\%$ \\
\hline Scientometrics & 13 & 15,3 \\
Information Processing \& Management & 12 & 14,1 \\
International Information \& Library Review & 8 & 9,4 \\
Journal of Information Science & 7 & 8,2 \\
Libri & 7 & 8,2 \\
Journal of the American Society for Information & & \\
$\quad$ Science \& Technology & 6 & 7,1 \\
Online Information Review & 3 & 3,5 \\
IFLA Journal & 2 & 2,4 \\
Information \& Management & 2 & 2,4 \\
Information Research & 2 & 2,4 \\
Journal of Academic Librarianship & 2 & 2,4 \\
Journal of Documentation & 2 & 2,4 \\
Journal of Librarianship \& Information Science & 2 & 2,4 \\
Proceedings of the ASIST Annual Meeting & 2 & 2,4 \\
Telecommunications Policy & 2 & 2,4 \\
Unesco Journal of Information Science Librarianship & & \\
$\quad$ \& Archives Administration & 2 & 2,4 \\
Diğer & 11 & 12,9 \\
Toplam & 85 & 100,3 \\
\hline
\end{tabular}

Not: Yuvarlama nedeniyle toplam yüzdesi \% 100'den fazladır. 
İranlı araştırmacıların yayın yaptıkları dergiler ile Türk araştırmacıların yayın yaptıkları dergilerin sıralamaları arasında orta düzeyde ve istatistiksel açıdan anlamlı bir korelasyon olduğu gözlenmiştir (Spearman's rho $=.64$, $p<.05)$. Öte yandan hem İranlı hem de Türk araştırmacıların bazı dergilerde hiçbir şekilde yayınlarının olmadığı saptanmıştır. Bunlar arasında Information Technology \& Libraries, Journal of Education for Library \& Information Science, Library Hi Tech, Library \& Information Science Research, Library Resources \& Technical Services, Library Trends, Portal-Libraries and the Academy ve Wilson Library Bulletin gibi dergiler bulunmaktadır.

Çalışmamızda, bir derginin ISI tarafından saptanan etki faktörünün yüksek olması ile İranlı ve Türk araştırmacılar tarafından bilgibilim dergilerinde daha fazla sayıda yayın yapııp yapılmadığı da araştııımıştır. Buna göre etki faktörü değerleri ile hem İranlı, hem de Türk araştırmacıların dergilerdeki yayın sayıları arasında istatistiksel yönden anlamlı bir korelasyon gözlenmemiştir (sırasıyla Pearson's $r=-.192 p=.45$ ve Pearson's $r=.196 p=.36$ ). Bu durum dergilerin etki faktörlerinin yüksek olmasından dolayı o dergide daha fazla yayın yapılmasının söz konusu olmadığını ortaya koymaktadır. Ayrıca etki faktörü en yüksek beş bilgibilim dergisinde yapılan yayınlara da bakılmıştır. Buna göre, söz konusu dergilerde İran adresli herhangi bir yayına rastlanmazken, Türkiye adresli yedi yayın (altısı Journal of the American Society for Information Science \& Technology'de, biri Journal of the American Medical Informatics Association adlı dergilerde olmak üzere) bulunmaktadır. Etki faktörü ile ilgili bulgular, İran ve Türkiye adresli olarak bilgibilim dergilerinde yapılan yayınlarda etki faktörünün söz konusu dergilerde yayın yaparken dikkat edilen bir unsur olmadığını göstermektedir.

\section{Atıflar}

Bilgibilim dergilerindeki İran adresli yayınların almış olduğu ortalama atıf sayısı 3'tür. Yayınların yarısından fazlasının atıf almadığı bilindiğine göre, bu rakamın ortaya çıkmasında birkaç yayının etkili olduğu söylenebilir. Tek tek yayınların almış olduğu atıf sayılarına bakıldığında; bir yayına 70, bir diğerine ise 39 kez atıf yapıldığı görülmektedir. Türkiye adresli yayınlarda İran adresli yayınlara oranla atıf almayan yayınların daha az olduğu görülürken yayın başına düşen atıf sayısı 2'dir. En çok atıf alan Türkiye adresli yayının toplam 14 atıfa sahip olduğu saptanmıştır. İran adresli 55 yayına $173 \mathrm{kez}$ atıf yapılırken Türkiye adresli 85 yayına 163 kez atıf yapıldığı görülmektedir. 
Tablo 7: Yayın ve Makalelerin Almış Oldukları Atıf Sayısına Göre Dağılımı

\begin{tabular}{|l|r|r|r|r|r|r|r|r|}
\hline \multirow{2}{*}{$\begin{array}{l}\text { Atıf } \\
\text { sayısı }\end{array}$} & \multicolumn{4}{|c|}{ Iran } & \multicolumn{4}{c|}{ Türkiye } \\
\cline { 2 - 9 } & \multicolumn{2}{|c|}{ Yayın } & \multicolumn{2}{c|}{ Makale } & \multicolumn{2}{c|}{ Yayın } & \multicolumn{2}{c|}{ Makale } \\
\cline { 2 - 9 } & $\mathbf{N}$ & $\%$ & $\mathrm{~N}$ & $\%$ & $\mathrm{~N}$ & $\%$ & $\mathrm{~N}$ & $\%$ \\
\hline 0 & 28 & 50,9 & 24 & 48,0 & 40 & 47,1 & 35 & 45,5 \\
\hline 1 & 11 & 20,0 & 11 & 22,0 & 17 & 20,0 & 15 & 19,5 \\
\hline 2 & 4 & 7,3 & 4 & 8,0 & 4 & 4,7 & 4 & 5,2 \\
\hline 3 & 7 & 12,7 & 7 & 14,0 & 5 & 5,9 & 5 & 6,5 \\
\hline 4 & - & - & - & - & 7 & 8,2 & 7 & 9,1 \\
\hline 5 & 1 & 1,8 & 1 & 2,0 & 3 & 3,5 & 3 & 3,9 \\
\hline$>5$ & 4 & 7,3 & 3 & 6,0 & 9 & 10,6 & 8 & 10,3 \\
\hline Toplam & 55 & 100,0 & 50 & 100,0 & 85 & 100,0 & 77 & 100,0 \\
\hline
\end{tabular}

\section{Yazarlar}

SSC/de yer alan bilgibilim dergilerinde yayımlanmış İran adresli yayınlar 46 farklı araştırmacının katkısı ile hazırlanmıştır. Yazarların \% 43'ü bilgibilim dergilerinde sadece bir kez görünmektedir. Beş ya da daha fazla yayın ile katkıda bulunan yazarlar SJ Haider, KS Umapathy, D Alimohammadi, JF Harvey ve F Osareh'dir. Bu kişilerin tamamı bilgibilim alanında görev yapan araştırmacılardır. Bilgibilim dergilerinde İran adresli yayın yapan araştırmacıları üç grupta toplamak olanaklıdır. Bu gruplar, İran'a gelen yabancı araştırmacılar, yurt dışında eğitim görüp İran'a gelmiş İranlı araştırmacılar ve lisansüstü eğitimlerini İran'da yapan ya da yapmakta olan araştırmacılar şeklinde sıralanabilir. Bu gruplara yukarıda sözü edilen verimli yazarlar açısından bakıldığında, söz konusu beş yazarın bu üç gruba dağılımı şu şekildedir:

Umapathy ve Harvey gibi verimli yazarlar İran kökenli değildirler ve yurt dışından gelip İran'daki üniversitelerde görev yapmışlardır. Haider ve Osareh yurt dışında eğitim görüp İran'da çalışan akademisyenlerdendir. Alimohammadi ise İran sınırları içinde doktora yapan grubun en verimli yazarı olarak göze çarpmaktadır.

Türkiye adresli 85 yayın 88 araştırmacı tarafından meydana getirilmiştir. Bu yayınlarda literatürde bir kez görünme oranı \% 73'tür. Sekiz araştırmacının üç ya da daha fazla sayıda yayına katkı yaptığı görülmektedir. Türkiye adresli yayınlara yazarların bağlı olduğu bölümler bağlamında bakıldığında, bilgibilim alanı dışında görev yapmakta olan bazı araştırmacıların, bu alanda oldukça aktif oldukları görülmektedir. Örnek ver- 
mek gerekirse; Hüseyin Cenk Özmutlu alandaki en verimli kişi (10 yayın ile) olarak görünmektedir ve kendisi endüstri mühendisidir. Yine endüstri mühendisi olan Seda Özmutlu ile İstatistik Bölümü öğretim üyesi Ali Uzun bilgibilim alanı dışında görev yapan ve bilgibilim dergilerinde en fazla yayına sahip araştırmacılardır. Bilgibilim alanındaki en verimli araştırmacı, halen Hacettepe Üniversitesi Bilgi ve Belge Yönetimi Bölümü'nde öğretim üyesi olarak görev yapan Yaşar Tonta'dır.6

Çalışmamızda atıf dizinleri kapsamındaki bilgibilim dergilerinde yapılan yayınların ne kadarının bilgibilim kökenli araştırmacılar tarafından gerçekleştirildiğine de bakılmaktadır. Bu bağlamda, iki ülke arasında dikkat çekici bir farklılık bulunmaktadır. İran adresli yayınların \% 80'inin yazarları doğrudan bilgibilim alanında çalışan kişiler iken, Türkiye için bu oran \% 34'te kalmaktadır. Bu durumun ortaya çıkmasında, Türkiye'de farklı alanlarda faaliyet gösteren akademisyenlerin bilgibilim dergilerinde yayın yapmaya ilgi duymalarının yanı sıra, bilgibilim alanındaki araştırmacıların da atıf dizinleri kapsamında yer alan bilgibilim dergilerinde pek fazla yayın yapma çabası içinde olmamaları önemli rol oynamaktadır.

Türkiye adresli yayınların İran adresli yayınlara oranla daha sık bir şekilde birden çok yazarın katkısı ile oluştuğu görülmektedir. Tek yazarlı yayınların oranı Türkiye adresli yayınlarda yaklaşık olarak yarı yarıya iken; İran adresli yayınlarda \% 70'e yakındır. Aynı zamanda Türkiye adresli yayınlar için ortalama yazar sayısı $(1,8)$ İran adresli yayınlara $(1,4)$ oranla daha yüksektir.

Tablo 8: Yayınların Yazar Sayısına Göre Dağılımı

\begin{tabular}{lrrrr} 
& \multicolumn{2}{c}{ İran } & \multicolumn{3}{c}{ Türkiye } \\
\hline Yazar sayısı & $\mathbf{N}$ & $\%$ & N & $\%$ \\
\hline 1 & 38 & 69,1 & 43 & 50,6 \\
2 & 13 & 23,6 & 24 & 28,2 \\
3 & 3 & 5,5 & 13 & 15,3 \\
4 & 1 & 1,8 & 2 & 2,4 \\
5 & - & - & 3 & 3,5 \\
\hline Toplam & 55 & 100,0 & 85 & 100,0 \\
\hline
\end{tabular}

6 Tonta'nın atıf dizinleri kapsamında toplam 11 yayını bulunmaktadır. Araştırmacı Türkiye dışında bulunduğu sürelerde de bilgibilim dergilerinde makale yayımlamıştır. Fakat çalışmamız kapsamında sadece Türkiye adresli yayınlar incelendiği için 7 yayını değerlendirilmiştir. Benzer durumda olan Iranlı araştırmacılar (Osareh gibi) da vardır. 


\section{Sonuç}

Dünya bilgibilim literatürüne yapılan katkının önemli ölçüde Batı kaynaklı olduğu bilinmektedir. Bununla birlikte İran ve Türkiye gibi elinde ciddi bir potansiyel olan ülkelerin söz konusu alana olan katkılarının son derece az olması oldukça düşündürücüdür. Çalışmamızda iki ülkenin en üretken olduğu dönem olan 1997-2006 arasını kapsayan dönemde bile yayınlar bazında on binde sekiz $(\%, 0,08)$, makale bazında on binde otuz sekizlik $(\%, 0,38)$ katkı yaptıkları görülmektedir. Çok daha küçük ülkelerin tek başına yaptığı katkının, çalışmamıza konu olan iki ülkenin yayın ve makale sayısı toplamından bile fazla olması endişe vericidir.

İran'ın bilgibilim alanında yurt dışındaki okullarda giderek artan sayıda öğrencisi yetişmektedir. Bu öğrencilerin ülkelerine dönmeleri sonucunda gerçekleştirecekleri çalışmalar ile İran'ın bilimsel yayın sayısının artmasına katkı sağlayacakları açıktır. Zaten daha önceki bazı örneklerde bu durumun oldukça gerçekçi olduğunu düşündürmektedir. Bu duruma Türkiye açısından bakıldığında, bilgibilim alanında yurt dışına giden araştırmacı sayısının çok fazla olmadığı bilinmektedir.

İki ülkede yayın sayılarının artmasını teşvik edici birtakım uygulamalar gerçekleştirilebilir. Örneğin, dernekler (Üniversite ve Araştırma Kütüphanecileri Derneği, İran Kütüphaneciler Derneği vb.) tarafından bilgibilim dergilerinde yapılacak yayınlar belli oranda desteklenebilir. Yayınlara yönelik olarak nicelik probleminin çözümlenmesinden sonra ele alınacak konu, yayınların niteliği olmalıdır. Bu bağlamda alandaki önemli kişilerle ortak araştırmalar yapmak için çalışılmalı, projeler gerçekleştirilmeli ve proje çıktıları yayın olarak kaliteli bilgibilim dergilerinde yayımlanmalıdır.

Atıf dizinleri kapsamında yayın yapan kişilerin çoğunlukla akademisyen oldukları görülmüştür. Alanla ilgili olarak uygulamada çalışanların yaptığı katkı neredeyse yok denecek kadar azdır. Oysaki uygulamadaki kişilerin deneyimlerini aktardıkları çalışmalar da birçok konuda yapılan teorik çalışmalar kadar değerlidir. Bu nedenle çalışmaların sadece akademik camia tarafından üretilmesi beklenmemelidir.

Atıf dizinlerinde yayın sahibi olmak kadar, dergilerin bu dizinlere girmesi de önemlidir. Halen bilgibilim alanında, ne İran'ın ne de Türkiye'nin herhangi bir dergisi atıf dizinleri kapsamında yer almamaktadır. Dergilerde yayımlanan makalelerin daha geniş kitlelerce erişilmesini sağlamak amacıyla, İran ve Türkiye'deki bilgibilim dergilerinin atıf dizinlerine girmesi yolunda çalışmalar yapılmalıdır. 


\section{Kaynakça}

Al, U., Şahiner, M. ve Tonta, Y. (2006) Arts and humanities literature: Bibliometric characteristics of contributions by Turkish authors. Journal of the American Society for Information Science \& Technology, 57 (8), 1011-1022.

Atamer, H., Dorsan, K., Önder, L. ve Torun, K. (2002). 70 bin araştırmaya 5 trilyon teşvik. Cumhuriyet Bilim Teknik, 823, 10-11.

Côté, G. ve Archambault, E. (2005). Scientific collaboration between Canada and developing countries, 1992-2003. Office of the National Science Advisor Privy Council Office Government of Canada için hazırlanmış rapor. 10 Nisan 2006 tarihinde http://www.sciencemetrix.com/pdf/SM_2005_002_CNS_Collaboration_CanadaDeveloping_Countries.pdf adresinden erişildi.

Ebrami, H. (1975). Libraries in Iran. Encyclopedia of Library \& Information science. Eds. A. Kent, H. Lancaster ve J.E. Dailey, New York: Marcel Dekker. 13, 15-53.

Ensafi, S. ve Gharibi, H. (2002). Iran knowledge in international level: 1999. Tahran: IRANDOC.

Ensarı, N. (1975). Karnameye se saleye amuzeş ketabdarı der dorehaı kotah modet" [Üç yıllık kısa dönem kütüphanecilik eğitimi raporu] Nameye Encumene Ketabdaran Iran. 8(4), 526-542.

Ersoy, O. (1969). Ankara Üniversitesi DTCF Kütüphanecilik Bölümünü'nün onbeş yılı. Türk Kütüphaneciler Derneği Bülteni, 18 (4), 228-231.

Garfield, E. (1983). Third world research. Part 1. Where it is published, and how often it is cited. Essays of Information Scientists, 6, 253-263. 31 Mart 2006 tarihinde http://www.garfield.library.upenn.edu/ essays/v6p253y1983.pdf adresinden erişildi.

Garfield, E. (1994). The ISI impact factor. Current Contents, 25, 3-7. 11 Ekim 2006 tarihinde http://scientific.thomson.com/free/essays/journalcitationreports/impactfactor/ adresinden erişildi.

Gülgöz, S., Ö. A. Yedekçioğlu ve E. Yurtsever. (2002). Turkey's output in social science publications: 1970-1999. Scientometrics, 55 (1), 103-121.

Harvey, J. (1989). Iranian information education. Journal of Education for Library and Information Science. 29 (3), 177-96. 
Herrero-Solana, V. ve Ríos-Gómez, C. (2006). Producción latinoamericana en biblioteconomía y documentación en el Social Science Citation Index (SSCI) 1966-2003. Information Research, 11 (2), paper 247. 28 Mart 2006 tarihinde http://informationr.net/ir/11-2/paper247.html adresinden erişildi.

ISI. (2006). Social Sciences Citation Index. 31 Mart 2006 tarihinde http:// portal.isiknowledge.com adresinden erişildi.

ISI. (2004). Journal Citation Reports. 31 Mart 2006 tarihinde http://jcrweb.com adresinden erişildi.

Küçük, M. E. (2004). Değerli bilgi çalışanları. (Editoryal). Türk Kütüphaneciliği, 18 (4), 361-362.

Kum, i. ve Erdoğan, P. L. (1980). Turkish library developments. Unesco Journal of Information Science, Librarianship and Archives Administration, 2 (4), 252-256.

LISDIRAN. (2006). Library and Information Science Directory of Iran. 21 Mart 2006 tarihinde http://www.nouruzi.itgo.com/LISDIRAN/directory.html adresinden erişildi.

Line, M. B. (1970). The 'half-life' of periodical literature: Apparent and real obsolescence. Journal of Documentation, 26, 46-54

Mehrdad, M., Heydari, A., Sarbolouki, M. N. ve Etemad, S. (2004). Basic science in the Islamic Republic of Iran. Scientometrics, 61 (1), 79-88.

Mezinani, A. (2000). Ketab ve ketabdari [Kitap ve Kütüphanecilik]. Tahran: Semt.

Moin, M., Mahmoudi, M. ve Rezaei, N. (2005). Scientific output of Iran at the threshold of the 21st century. Scientometrics, 62 (2), 239-248.

Mortezayi, L. (2000). Berresiyi vezeyet tehsilat tekmili olum ketabdarı der keşverhayı Engelestan, Amrika, Hend ve Iran. [İngiltere, Amerika Birleşik Devletleri, Hindistan ve İran'da lisansüstü kütüphanecilik eğitiminin incelenmesi]. FasInameye Olum Etelaeresanı, 15 (3). 21 Mart 2006 tarihinde http://www.irandoc.ac.ir/Journals/jr15.htm adresinden erişildi.

Osareh, F. ve Wilson, C. S. (1997). Third World Countries (TWC) research publications by disciplines: A country-by-country citation analysis. Scientometrics, 39 (3), 253-266.

Osareh, F. ve Wilson, C. S. (2000). A comparison of Iranian scientific publications in the Science Citation Index: 1985-1989 and 1990-1994. Scientometrics, 48 (3), 427-442. 
Osareh, F. ve Wilson, C. S. (2002). Collaboration in Iranian scientific publications. Libri, 52, 88-98.

Ötüken, A. (1979). Kütüphaneciliğimiz için...: Milli Kütüphane nasıl kuruldu ve Türkiye'de kütüphanecilik öğretiminin tarihçesi. Ankara: TKD.

Schloegl, C. ve Stock, W. G. (2004). Impact and relevance of LIS journals: A scientometric analysis of international and German-language LIS journals-citation analysis versus reader survey. Journal of the American Society for Information Science \& Technology, 55 (13), 1155-1168.

Soltani, P. ve Rastin, F. (2001). Daneşnameye Kitabdarı: Ferheg-i Ingilisi be Farsi [íngilizce - Farsça Kütüphanecilik Ansiklopedik Sözlügü]. Tahran: Farhang Moaser.

Tonta, Y. ve M. İlhan. (1997). Sosyal bilimlerde Türkiye'nin dünyadaki yeri. Türk Psikoloji Dergisi, 12 (40), 67-74.

Uzun, A. (1996). A bibliometric analysis of physics publications from Middle Eastern countries. Scientometrics, 36 (2), 259-269.

Uzun, A. (1998). A scientometric profile of social sciences research in Turkey. International Information \& Library Review, 30 (3), 169-184.

Uzun, A. (2002). Library and information science research in developing countries and Eastern European countries: A brief bibliometric perspective. International Information \& Library Review, 34 (1), 21-33.

Wilson, C. S. ve Osareh, F. (2003). Science and research in Iran: A scientometric study. Interdisciplinary Science Reviews, 28 (1), 26-37.

Yurtsever, E., S. Gülgöz, Ö. A. Yedekçioğlu ve M. Tonta. (2001). Sosyal Bilimler Atıf Dizini'nde (SSCI) Türkiye: 1970-1999. Ankara: TÜBA.

Yurtsever, E., S. Gülgöz, Ö. A. Yedekçioğlu ve M. Tonta. (2002). Sağlık bilimleri, mühendislik ve temel bilimlerde Türkiye'nin uluslararası atıf dizinindeki yeri: 1973-1999. Ankara: TÜBA. 